\title{
Entrepreneurial Activities in Rural Forest Communities in Nigeria: Case Study of Onigambari Forest Area, Ibadan, Oyo State, Nigeria
}

\author{
Oyetunji, P. O.* Fadele, O. A. Ibitoye, S. O. \\ Forestry Research Institute of Nigeria, Ibadan, Oyo State, Nigeria
}

\begin{abstract}
Entrepreneurship has been identified as a vehicle for rural development and overall economic growth in Nigeria. This paper examines the nature of entrepreneurial ventures in rural forest communities as well as the roles of forest resources in these ventures and the challenges they face. The study was based on a survey of 120 respondents from three communities in the Onigambari Forest Area in Oyo State using multistage sampling technique. Descriptive statistics as well as the Chi - square was used to analyse the results. The results showed that the farming (agribusiness) form the major entrepreneurial venture in these communities and these ventures are faced with a vicious cycle of low income and productivity. The results also show that these entrepreneurial ventures are faced with several challenges affecting their productivity. This study recommends that the government should encourage financial institutions to increase their presence in rural areas, that members in forest communities should be adequately trained on how to make proper use of forest resources and the overall standard of living in rural areas should be improved so that entrepreneurship can have the desired effect and forest resources can be a productive asset for development in these communities.
\end{abstract}

Keywords: Entrepreneurship, forest resources, rural areas

DOI: $10.7176 /$ RHSS/9-11-08

Publication date:June $30^{\text {th }} 2019$

\section{Introduction}

Entrepreneurship has become a common concept in the world today with a lot of implications for both developed and developing nations. Entrepreneurship in Nigeria is usually seen in the form of Micro, Small and Medium scale enterprises (MSMEs). According to Osunde (2016), MSMEs as reported by the Small and Medium Enterprises Development of Nigeria (SMEDAN) represent $96 \%$ of the businesses in Nigeria and contributes $75 \%$ of the national employment. This huge number indicates that small businesses are the backbone of the Nigerian economy. A nation's ability to generate a steady stream of business opportunities can only come about when its people take on entrepreneurial activities (Ihugba, Odii and Njoku, 2013). Entrepreneurial thinking and competent action increase the economic and social standards of the rural and urban population and the ability to mobilize the full economic potential of a country is thus related to its culture of entrepreneurship (Schmithusen, Kaiser, Schmidhauser, Mellinghof, Perchthaler and Kammerhofer, 2014).

Entrepreneurship plays a very important role in the society. According to Oriola (2009), development can be seen as a justifiable utilization of local resources for the improved living conditions or standard of living for all the inhabitants of a community, state or nation. Rural entrepreneurship can help to increase output, create employment, reduce rural - urban migration, reduce poverty levels and in general improve living conditions in the rural areas (Nwankwo and Okeke, 2017). Therefore, for rural communities in Nigeria to develop, rural entrepreneurship must be encouraged. The need for rural development in Nigeria is emphasized in the growing disparities between the level of infrastructure as well as poverty levels. According to Osunde (2016), a rural entrepreneur is an individual who resides in the rural area and establishes a business venture in the community that contributes to the economic development of that area and as such is usually community based. Rural entrepreneurship refers to all business undertakings among rural dwellers aimed at income generation while also providing a source of livelihood (Olowookere and Elegbeleye, 2014).

Entrepreneurship also brings out the benefits of forests resources in Nigeria. According to Schmithusen et al (2014), forests contribute to poverty alleviation, rural development, green jobs, renewable bio-energy, energy security, climate change adaptation and mitigation, soil and water conservation, biodiversity protection, sustainable building and city development. Entrepreneurship in forest areas is the only way to harness forest resources as well as other available resources for development. Forest resources have an extensive value chain that can extend from the creation of saw mills, furniture making establishments etc. These entrepreneurial ventures will create employment for the rural population which will improve health and education conditions in these areas. Also, as the standard of living improves, there will be a reduced pressure on forest resources improving environmental sustainability and reducing the rates of deforestation in those areas. As entrepreneurship activities improve in rural forest communities, they also ensure a general improvement in the level of infrastructure. 
The Nigerian government has made several efforts in a bid to improve entrepreneurial and business ventures in the country. According to Idam (2014), these efforts include the creation of the Small and Medium Industries Equity Investment Scheme (SMIEIS), Bank of Industry (BOI), Nigerian Agricultural Cooperative Rural Development Bank (NACRDB), Microfinance bank, National Directorate of Employment (NDE), SMEDAN, Entrepreneurship Development Centres (EDCs) and the Youth Enterprise with Innovation in Nigeria (YouWIN). Despite these efforts, the level of business growth and expansion in Nigeria has still been poor especially in rural areas. These government interventions are also not very common in these rural areas leading to reduced effectiveness.

Entrepreneurial ventures in Nigeria are faced with several challenges which have undermined the efforts of the government. Ihugba, et al (2013) mentioned that insecurity and government policies have had negative consequences on the success rates of businesses in Nigeria. Challenges facing Small and Medium scale enterprises in rural areas include poor road networks, high cost of borrowing, epileptic power supply, low levels of education, poor health facilities as well as inadequate family planning methods (Osunde, 2016). Lack of access to information regarding government efforts on MSMEs development may also contribute to the challenges facing entrepreneurs in rural areas. Also, businesses in rural areas may also lack the appropriate technology to harness local resources especially in forest communities. According to Azeez, Awe, Ajibola and Amoo (2011), provision of credit facilities are necessary for rural populations to be able to mobilize resources to more productive uses but this may be difficult given the inefficiencies in the Nigerian credit market.

Formal entrepreneurship trainings are very common in urban areas especially among youths and business ventures seeking expansion but these trainings are not very common in rural areas. Furthermore, in order to have access to some of the government's schemes and programs, business ventures need to be organized and registered with the appropriate authorities. Business ventures in rural communities have no structure, no funds and in many cases no information regarding these processes thereby shutting them out from these schemes and programs. In rural forest communities, the level of technology is very low and as such the ability to transform both timber and non - timber forest products into other products is limited. All these issues need to be addressed for entrepreneurial and business activities to thrive in rural forest communities in Nigeria.

A lot of studies have focused on the entrepreneurial and business activities in urban areas. However, not much work has been done on rural areas and very few works have been done on forest communities in Nigeria. Therefore, this study will seek to identify the entrepreneurial and business activities existing in rural forest communities, the challenges faced by these ventures as well as the effects of these ventures on deforestation.

\section{Materials and Methods}

\subsection{Study Area}

This study was carried out in the forest based communities around the Onigambari Forest Reserve, Ibadan, Oyo State, Nigeria. These communities include Onipe, Ibusogboro and Onigambari. These communities were chosen because of the close proximity to the surrounding forests as well as the high levels of interaction the community dwellers have with the forest.

\subsection{Sources of Data}

The data used in this study was collected with the aid of well structured questionnaires. Information on the socio - economic characteristics and profiles of entrepreneurs was requested for. These include their age, gender, marital status and educational attainment. Also, the nature of entrepreneurial activities, income gained from the venture, the role of forest resources and the challenges faced in these business ventures were also obtained. Furthermore, the perceptions of the entrepreneurs on issues regarding conservation were also requested for.

\subsection{Sampling Technique}

The study employs multistage stage sampling technique. The first stage is Purposive selection of 40 entrepreneurs per community. The second stage involves a random selection of the entrepreneurs among the entire population. A total of a hundred and twenty (120) questionnaires were administered. Care was taken to ensure total inclusion and representation.

\subsection{Method of Data Analysis}

Simple descriptive analysis was used to analyse the data. Frequency distribution and percentages were used as the simple descriptive statistics. Also, the Chi - Square was used to analyse the relationship existing between several variables.

\subsection{Results}

\section{Socio - Economic Characteristics of Respondents}

From Table 1 below, a greater percentage of the business ventures in forest communities are owned by younger 
Vol.9, No.11, 2019

people as 20 - 30 year olds form $25.8 \%$ and 30 - 40 years form $33.3 \%$ of the total respondents. Also, males form $46.7 \%$ of the total respondents while females form $53.3 \%$ of the total respondents. The table further shows that $11.7 \%$ of the entrepreneurs in the area have no education, $43.3 \%$ of the entrepreneurs have primary education, $44.2 \%$ of the respondents have secondary education while only $0.8 \%$ of the respondents have tertiary education. Furthermore, a great majority of the respondents are married with a percentage of $72.5 \%$ while $14.5 \%, 4.2 \%$ and $9.2 \%$ belong to the respondents in the single, divorced and widowed category respectively.

Table 1. Distribution of Respondents by Socio - Economic Characteristics

\begin{tabular}{|c|c|c|c|c|c|}
\hline & & Frequency & Percent & $\begin{array}{c}\text { Valid } \\
\text { Percent }\end{array}$ & $\begin{array}{c}\text { Cumulative } \\
\text { Percent }\end{array}$ \\
\hline \multirow[t]{6}{*}{ Age } & $20-30$ years & 31 & 25.8 & 25.8 & 25.8 \\
\hline & $30-40$ years & 40 & 33.3 & 33.3 & 59.2 \\
\hline & $40-50$ years & 28 & 23.3 & 23.3 & 82.5 \\
\hline & $50-60$ years & 17 & 14.2 & 14.2 & 96.7 \\
\hline & 60 and above & 4 & 3.3 & 3.3 & 100.0 \\
\hline & Total & 120 & 100.0 & 100.0 & \\
\hline \multirow[t]{3}{*}{ Gender } & Male & 56 & 46.7 & 46.7 & 46.7 \\
\hline & Female & 64 & 53.3 & 53.3 & 100.0 \\
\hline & Total & 120 & 100.0 & 100.0 & \\
\hline \multirow[t]{5}{*}{ Educational Attainment } & None & 14 & 11.7 & 11.7 & 11.7 \\
\hline & Primary School & 52 & 43.3 & 43.3 & 55.0 \\
\hline & Secondary School & 53 & 44.2 & 44.2 & 99.2 \\
\hline & Tertiary Education & 1 & .8 & .8 & 100.0 \\
\hline & Total & 120 & 100.0 & 100.0 & \\
\hline \multirow[t]{5}{*}{ Marital Status } & Single & 17 & 14.2 & 14.2 & 14.2 \\
\hline & Married & 87 & 72.5 & 72.5 & 86.7 \\
\hline & Divorced & 5 & 4.2 & 4.2 & 90.8 \\
\hline & Widowed & 11 & 9.2 & 9.2 & 100.0 \\
\hline & Total & 120 & 100.0 & 100.0 & \\
\hline
\end{tabular}

Source: Field Survey, 2019

\section{Entrepreneurial Ventures}

From Table 2, farming (agribusiness) is the major entrepreneurial venture in these communities with $63.3 \%$ of the respondents. The other business ventures identified by the respondents are artisans, fuelwood selling and petty trading with $11.7 \%, 17.5 \%$ and $7.5 \%$ respectively. The table shows that obtaining a source of income formed a major purpose for starting a business venture with $72.5 \%$ of the respondents while $27.5 \%$ of the respondents identified family tradition as the purpose for starting the venture. It can also be observed that $75.8 \%$ of the respondents participated in some form of apprenticeship while $24.2 \%$ of the respondents did not participate in any form of apprenticeship. Table 2 also reveals that $76.7 \%$ of the respondents had apprentices under their care while $23.3 \%$ did not have any apprentices under their tutelage.

Table 2. Distribution of Respondents by Nature of Entrepreneurial Ventures

\begin{tabular}{|l|l|r|r|r|r|}
\hline & & Frequency & Percent & \multicolumn{1}{c|}{$\begin{array}{l}\text { Valid } \\
\text { Percent }\end{array}$} & $\begin{array}{l}\text { Cumulative } \\
\text { Percent }\end{array}$ \\
\hline Entrepreneurial Ventures & Artisan & 14 & 11.7 & 11.7 & 11.7 \\
\hline & $\begin{array}{l}\text { Farming } \\
\text { (Agribusiness) }\end{array}$ & 76 & 63.3 & 63.3 & 75.0 \\
\hline & Fuelwood Selling & 21 & 17.5 & 17.5 & 92.5 \\
\hline & Petty Trading & 9 & 7.5 & 7.5 & 100.0 \\
\hline & Total & 120 & 100.0 & 100.0 & \\
\hline Purpose of Entrepreneurial Venture & Source of income & 87 & 72.5 & 72.5 & 72.5 \\
\hline & Family Tradition & 33 & 27.5 & 27.5 & 100.0 \\
\hline & Total & 120 & 100.0 & 100.0 & \\
\hline Apprenticeship Participation & Yes & 91 & 75.8 & 75.8 & 75.8 \\
\hline & No & 29 & 24.2 & 24.2 & 100.0 \\
\hline & Total & 120 & 100.0 & 100.0 & \\
\hline Apprentices Under Tutelage & Yes & 92 & 76.7 & 76.7 & 76.7 \\
\hline & No & 28 & 23.3 & 23.3 & 100.0 \\
\hline & Total & 120 & 100.0 & 100.0 & \\
\hline
\end{tabular}

Source: Field Survey, 2019 
Table 3 shows that $46.7 \%$ of the respondents make use of markets to perform their business activities. This could be because markets are more likely to attract more customers. $30.8 \%$ of the respondents have their farms as their business location while roadsides, shops and factories/workshops were chosen by $13.3 \%, 2.5 \%$ and $6.7 \%$ of the respondents respectively. Most of the customers of business ventures among the respondents are members of the community with $51.7 \%$ while outsiders and travelers are customers for $39.2 \%$ and $9.2 \%$ respectively of the total respondents. $36.7 \%$ of the respondents buy the raw materials or major items used in the entrepreneurship venture while $63.3 \%$ of the respondents harvest these resources from the surrounding forest. $46.7 \%$ of the respondents earn less than 10000 per month from their venture, $22.5 \%$ of the respondents earn between $\$ 10000$ - $\$ 20000,7.5 \%$ earn between $\$ 20000$ - $\$ 30000$ while $23.3 \%$ of the respondents earn between $\$ 30000$ - $\$ 40000$. Furthermore, $7.5 \%$ of the respondents have no use for forest resources in their ventures with a majority using forest resources for benches, sheds, shops and furniture while only $1.7 \%$ use forest resources as raw materials.

Table 3. Distribution of Respondents by Characteristics of Business Ventures

\begin{tabular}{|c|c|c|c|c|c|}
\hline & & Frequency & Percent & $\begin{array}{l}\text { Valid } \\
\text { Percent }\end{array}$ & $\begin{array}{l}\text { Cumulative } \\
\text { Percent }\end{array}$ \\
\hline \multirow[t]{6}{*}{ Business Location } & Farm & 37 & 30.8 & 30.8 & 30.8 \\
\hline & Market & 56 & 46.7 & 46.7 & 77.5 \\
\hline & Roadside & 16 & 13.3 & 13.3 & 90.8 \\
\hline & Shop & 3 & 2.5 & 2.5 & 93.3 \\
\hline & Factory/Workshop & 8 & 6.7 & 6.7 & 100.0 \\
\hline & Total & 120 & 100.0 & 100.0 & \\
\hline \multirow[t]{4}{*}{ Customers } & Members of your community & 62 & 51.7 & 51.7 & 51.7 \\
\hline & Outsiders & 47 & 39.2 & 39.2 & 90.8 \\
\hline & Travellers & 11 & 9.2 & 9.2 & 100.0 \\
\hline & Total & 120 & 100.0 & 100.0 & \\
\hline \multirow[t]{3}{*}{ Raw Material Sourcing } & Buying & 44 & 36.7 & 36.7 & 36.7 \\
\hline & Harvesting & 76 & 63.3 & 63.3 & 100.0 \\
\hline & Total & 120 & 100.0 & 100.0 & \\
\hline \multirow[t]{5}{*}{ Income } & Less than 10000 & 56 & 46.7 & 46.7 & 46.7 \\
\hline & N10000 - 20000 & 27 & 22.5 & 22.5 & 69.2 \\
\hline & $\aleph 20000-N 30000$ & 9 & 7.5 & 7.5 & 76.7 \\
\hline & $\aleph 30000-N 40000$ & 28 & 23.3 & 23.3 & 100.0 \\
\hline & Total & 120 & 100.0 & 100.0 & \\
\hline \multirow[t]{6}{*}{$\begin{array}{l}\text { Role of Forest Resources in } \\
\text { Business Venture }\end{array}$} & None & 9 & 7.5 & 7.5 & 7.5 \\
\hline & Benches and Furniture & 41 & 34.2 & 34.2 & 41.7 \\
\hline & Sheds & 28 & 23.3 & 23.3 & 65.0 \\
\hline & Shops/Stands & 40 & 33.3 & 33.3 & 98.3 \\
\hline & Raw Materials & 2 & 1.7 & 1.7 & 100.0 \\
\hline & Total & 120 & 100.0 & 100.0 & \\
\hline
\end{tabular}

Source: Field Survey, 2019

\section{Challenges and Prospects of Entrepreneurial Ventures}

Table 4 below shows that $98.3 \%$ of the entrepreneurs required some funds to start their business venture while only $1.7 \%$ of the respondents indicated that no funds were needed in order for them to start their business venture. Table 4 also shows that the major source of funds for entrepreneurial ventures in these communities include personal savings. Loans and Assistance from family members were chosen by $20.0 \%$ and $12.5 \%$ of the respondents as source of funds. Only $2.5 \%$ of the respondents received their funds through grants and aid. This could be after the completion of a training program. Furthermore, the table shows that $30 \%$ of the respondents identified lack of funds as the challenge faced in their entrepreneurial venture, $20 \%$ of the respondents identified lack of patronage, $39.2 \%$ mentioned poor roads while $10.8 \%$ identified poor power supply as the challenge faced in entrepreneurial venture. 
Vol.9, No.11, 2019

Table 4. Distribution of Respondents by Challenges in Business Venture

\begin{tabular}{|l|l|r|r|r|r|}
\hline & & Frequency & Percent & \multicolumn{1}{|c|}{$\begin{array}{l}\text { Valid } \\
\text { Percent }\end{array}$} & $\begin{array}{l}\text { Cumulative } \\
\text { Percent }\end{array}$ \\
\hline $\begin{array}{l}\text { Need for Startup } \\
\text { Funds }\end{array}$ & Yes & 118 & 98.3 & 98.3 & 98.3 \\
\hline & No & 2 & 1.7 & 1.7 & 100.0 \\
\hline & Total & 120 & 100.0 & 100.0 & 65.0 \\
\hline Source of funds & Personal Savings & 78 & 65.0 & 65.0 & 85.0 \\
\hline & Loans & 24 & 20.0 & 20.0 & 97.5 \\
\hline & Assistance from Family & 15 & 12.5 & 12.5 & 100.0 \\
\hline & members & 3 & 2.5 & 2.5 & 30.0 \\
\hline & Grants and Aid & 120 & 100.0 & 100.0 & 50.0 \\
\hline Challenges & Lack of funds & 24 & 30.0 & 30.0 & 89.2 \\
\hline & Lack of patronage & 47 & 39.2 & 39.2 & 100.0 \\
\hline & Poor roads & 13 & 10.8 & 10.8 & \\
\hline & Poor power supply & 120 & 100.0 & 100.0 & \\
\hline & Total & & & & \\
\hline
\end{tabular}

Source: Field Survey, 2019

Table 5 below reveals that that $96.7 \%$ of the respondents have a desire for business expansion while $3.3 \%$ of the respondents do not have a plan or desire for expansion of their entrepreneurial venture. Table 5 also shows that $82.5 \%$ of the respondents have never undergone any formal training on entrepreneurship while $17.5 \%$ of the respondents have undergone formal entrepreneurship trainings and that $70 \%$ of the respondents indicated interest in participating in formal trainings on entrepreneurial activities while $30 \%$ of the respondents were not willing to participate in any formal training on entrepreneurship. The table further shows that $75 \%$ of the respondents are not aware of any government assistance on entrepreneurship while $25 \%$ of the respondents are aware of government assistance for entrepreneurs and while $40 \%$ of the respondents indicated that government should increase provision of funds, $58.3 \%$ of the respondents indicated government should improve the road networks and provide other basic social amenities and $1.7 \%$ of the respondents indicated that the government should provide training facilities.

Table 5. Distribution of Respondents by Trainings and Government Assistance

\begin{tabular}{|c|c|c|c|c|c|}
\hline & & Frequency & Percent & $\begin{array}{l}\text { Valid } \\
\text { Percent }\end{array}$ & $\begin{array}{l}\text { Cumulative } \\
\text { Percent }\end{array}$ \\
\hline \multirow[t]{3}{*}{ Plans for Expansion } & Yes & 116 & 96.7 & 96.7 & 96.7 \\
\hline & No & 4 & 3.3 & 3.3 & 100.0 \\
\hline & Total & 120 & 100.0 & 100.0 & \\
\hline \multirow[t]{3}{*}{$\begin{array}{l}\text { Participation in Formal } \\
\text { Entrepreneurship Training }\end{array}$} & Yes & 21 & 17.5 & 17.5 & 17.5 \\
\hline & No & 99 & 82.5 & 82.5 & 100.0 \\
\hline & Total & 120 & 100.0 & 100.0 & \\
\hline \multirow[t]{3}{*}{$\begin{array}{l}\text { Willingness to Partake in } \\
\text { Formal Training }\end{array}$} & Yes & 84 & 70.0 & 70.0 & 70.0 \\
\hline & No & 36 & 30.0 & 30.0 & 100.0 \\
\hline & Total & 120 & 100.0 & 100.0 & \\
\hline \multirow[t]{3}{*}{$\begin{array}{l}\text { Awareness of Government } \\
\text { Assistance }\end{array}$} & Yes & 30 & 25.0 & 25.0 & 25.0 \\
\hline & No & 90 & 75.0 & 75.0 & 100.0 \\
\hline & Total & 120 & 100.0 & 100.0 & \\
\hline \multirow[t]{4}{*}{ Government Assistance } & Provision of funds & 48 & 40.0 & 40.0 & 40.0 \\
\hline & $\begin{array}{l}\text { Improvement of roads and } \\
\text { other basic social amenities }\end{array}$ & 70 & 58.3 & 58.3 & 98.3 \\
\hline & Training facilities & 2 & 1.7 & 1.7 & 100.0 \\
\hline & Total & 120 & 100.0 & 100.0 & \\
\hline
\end{tabular}

Source: Field Survey, 2019

\section{Perceptions on Deforestation}

Table 6 reveals that $95.8 \%$ of the respondents are aware of the reduction of forest resources in their communities while $4.2 \%$ of the respondents are not aware of the increasing deforestation in their communities. The table also 
shows that $46.7 \%$ of the respondents believe that the forest resources in their communities can finish while $53.3 \%$ of the respondents indicated that they believe forest resources in their communities are inexhaustible and that $79.2 \%$ of the respondents believe they are entitled to make use of forest resources whenever they want while $20.8 \%$ of the respondents believe they are not entitled to make use of forest resources when they want.

Table 6. Distribution of Respondents by Perceptions on Deforestation

\begin{tabular}{|l|l|r|r|r|r|}
\hline & & Frequency & Percent & Valid Percent & Cumulative Percent \\
\hline Reduction of Forest Resources & Yes & 115 & 95.8 & 95.8 & 95.8 \\
\hline & No & 5 & 4.2 & 4.2 & 4.2 \\
\hline & Total & 120 & 100.0 & 100.0 & 46.7 \\
\hline Resource Exhaustibility & Yes & 56 & 46.7 & 46.7 & 100.0 \\
\hline & No & 64 & 53.3 & 53.3 & 79.2 \\
\hline & Total & 120 & 100.0 & 100.0 & 100.0 \\
\hline Forest Resource Entitlement & Yes & 95 & 79.2 & 79.2 & 20.8 \\
\hline
\end{tabular}

Source: Field Survey, 2019

Table 7. Educational Attainment/Income Chi - Square Test

\begin{tabular}{|l|l|l|l|}
\hline & Value & Df & Asymptotic Significance (2-sided) \\
\hline Pearson Chi-Square & $20.028^{\mathrm{a}}$ & 9 & .018 \\
\hline Likelihood Ratio & 20.447 & 9 & .015 \\
\hline Linear-by-Linear Association & 6.305 & 1 & .012 \\
\hline N of Valid Cases & 120 & & \\
\hline a. 9 cells (56.3\%) have expected count less than 5. The minimum expected count is .08. \\
\hline
\end{tabular}

Source: Author's Computation from SPSS 23

Table 25 shows that the relationship between educational attainment and income is significant at the $1 \%$ level.

\subsection{Discussion of Results}

This study seeks to determine the nature of entrepreneurial activities being undertaken in rural forest based communities, the role of forest resources in these ventures as well as the challenges faced by these business ventures. A total of 120 respondents were selected across 3 forest based communities using random selection across 3 communities in Ibadan. Descriptive statistics was used to analyze the data.

Table 1 illustrates that the age group with the highest involvement in entrepreneurial activities in the region are those between $30-40$ years representing $33.3 \%$ of the respondents. Table 1 further illustrates that while females consist of $53.3 \%$ of the total respondents. Chinonye, Iyiola and Akinbode (2015) corroborated this by stating that in developing countries, due to the increasing economic downturn leading to loss of jobs for men, women assume responsibility of microenterprises. This also shows that women should be targeted for funding opportunities by financial institutions as well as the government. The table also shows that primary and secondary education forms the major opportunities for education in these communities with $43.3 \%$ and $44.2 \%$ of the total respondents respectively with $11.7 \%$ of the respondents indicating that they have no educational qualifications. This reveals one of the major characteristics of rural communities which is the low level of education. According to the table, $72.5 \%$ of the total respondents are married. This shows that many of the entrepreneurial activities in these communities are run by households.

Table 2 also reveals that farming (agribusiness) is the major business activity being undertaken in these communities consisting about $63.3 \%$ of the respondents. Farming however, is not the only business activity as the some entrepreneurs in the communities are also artisans, petty traders and fuelwood traders. Table 3 also illustrates that obtaining a source of income was the primary purpose for engaging in entrepreneurial ventures in these communities. Osunde (2016) identified financial autonomy as one of the major reasons for starting new businesses in rural areas. Table 3 also shows that majority of the entrepreneurs harvest the raw materials used in their ventures and in many cases, these raw materials are harvested from the surrounding forest. According to Riti, Dankumo and Gubak (2015), environmental problems such as deforestation in Nigeria are caused majorly by economic activities by human activities on the environment in order to eke a living. The constant harvesting of forest resources for use in these entrepreneurial ventures has contributed to the rate of deforestation in the area. From Table 3, it can be observed that majority of the entrepreneurs earn less than 10000 a month from their ventures with majority of their customers being members of their community as seen in Table 10 and this indicates a vicious cycle of poverty and low productivity. Table 3 illustrates that forest resources are not judiciously used in these entrepreneurial ventures as they are mostly used for furniture, sheds, stands and shops. Nwankwo and Okeke (2017) mentioned that rural entrepreneurship can help develop rural areas through good 
management of local resources. Therefore, the communities should be educated and trained on proper management of forest resources as well as the various uses of forest resources so that the communities can adequately gain from the wide variety of products available via forest resources.

Table 4 shows that $98.3 \%$ of the respondents require some funds to start their venture while majority of these respondents obtain these funds via personal savings or through loans and assistance from family members as shown in Table 15 and this in line with the findings obtained by Fouda and Pene (2015). This is usually because financial institutions are not very common in rural areas and the entrepreneurs in many cases cannot afford to take loans from such banks. From Table 4, lack of funds, lack of patronage, poor roads and poor power supply were identified as challenges faced in the entrepreneurial ventures in the communities. This was corroborated in the findings of Diyoke (2014) who also included lack of organizational and management skills, market imperfections as well as restrictive effects of customs and traditions. According to Onyeka (2014), these basic infrastructures are necessary to boost entrepreneurship.

The results from Table 5 showed that only $17.5 \%$ of the respondents had participated in formal trainings on entrepreneurship but $70 \%$ of the respondents identified that they would be willing to participate in formal trainings on entrepreneurship as revealed in Table 19. Therefore, the government should create training facilities for the entrepreneurs so that they can be better equipped on management skills as well as provide the members of these communities with other viable business ventures. Also, Table 5 illustrates that $75 \%$ of the respondents are not aware of any government assistance on entrepreneurship and as such the government should spread the information concerning government assistance for entrepreneurs in rural areas. From Table 5, the respondents indicated that the government can assist entrepreneurial ventures in these communities via provision of funds, improvement of roads and other basic social amenities as well as the provision of training facilities. Idam (2014) corroborated this stating that the provision of infrastructural facilities like roads, water and proper power supply will go a long way to make the business environment more conducive.

Table 6 reveals that there is a high knowledge in the area on the reduction of the available forest resources but $53.3 \%$ of the respondents indicate that the forest resources in their surrounding area cannot finish with $79.2 \%$ of the respondents having a sense of entitlement in the use of forest resources in their communities. Therefore, the communities surrounding the forests should be trained and educated on conservation and forest protection so as to curb deforestation. Table 7 indicates the existence of a relationship between educational attainment and income. Therefore, as the entrepreneurs and members of the community have an increased access to formal education, their income from business activities will also increase. This is because education creates an avenue for increased exposure to better management techniques and technological advancements.

\section{Recommendations and Conclusion}

Rural development is very important for the development of any country. The utilization of local resources is necessary for rural development to occur and this is possible through rural entrepreneurship. Therefore, the judicious utilization of forest resources through entrepreneurship is very important for development in forest based communities in Nigeria.

The government needs to train rural forest based dwellers on the entrepreneurial potentials that abound in forest resources so that these resources can be used more productively. Also, financial institutions need to increase their presence in these communities so that entrepreneurs have a wider range of funding options. Also, the government needs to raise the standard of living in these forest based communities by investing heavily in education and infrastructure like roads and power supply. This will reduce the cost of doing business, improve the business environment and increase the purchasing power of the members of the community thus increasing the productivity and profitability of the ventures.

Furthermore, the government and other relevant stakeholders need to increase formal trainings on entrepreneurship in these areas. This will provide the entrepreneurs with the needed skills to properly harness the resources around them. Also, increased community education will also help to ensure entrepreneurial activities in these communities do not further contribute to deforestation.

\section{References}

Azeez, F. A., Awe, F., Ajibola, A. O. and Amoo, M. A. (2011). Credit Characteristics of Forest Based Entrepreneurs in Iseyin Local Government Area, South West Nigeria. Journal of Ecology and Natural Environment, Vol. 3(9), pp. 304 - 308, 12 September, 2011

Chinonye, M. L., Iyiola, O. O., Akinbode, M. O., Obigbemi, I. A. and Eke, O. P. (2015). Women Entrepreneurship in Nigeria: Policy Framework, Challenges and Remedies. Kasmera, 43(2), 2015

Diyoke, C. I. (2014). Entrepreneurship Development in Nigeria: Issues, Problems and Prospects. International Journal of Technical Research and Applications, Special Issue 10(Nov - Dec 2014), pp. 19 - 23

Fouda, O. M. and Pene, Z. N. P. (2015). Entrepreneurship Development in a Local Context: Evidence from Entrepreneurs in the Eastern Region of Cameroon. Applied Economics and Finance, Vol. 2, No. 2; May 


\section{5}

Idam, L. E. (2014). Entrepreneurship Development in Nigeria: A Review. IOSR Journal of Business and Management (IOSR-JBM), Volume 16, Issue 1. Ver. IV (Jan. 2014), PP 01-07

Ihugba, O. A., Odii, A. and Njoku, A, C. (2013). Challenges and Prospects of Entrepreneurship in Nigeria. Academic Journal of Interdisciplinary Studies, Vol 2 No. 5, July 2013

Nwankwo, F. O. and Okeke, C. S. (2017). Rural entrepreneurship and rural development in Nigeria. Africa's Public Service Delivery and Performance Review, 5(1), a152.

Olowookere, E. I. and Elegbeleye, A. O. (2014). Relevance of Prosocial Behaviors to Rural Entrepreneurship Development in Nigeria. Case Studies Journal-Volume 3, Issue 4, 2014

Onyeka, U. O. (2014). Challenges Facing Entrepreneurship in Nigeria. International Journal of Business and Management; Vol. 9, No. 12; 2014

Osunde, C. (2016). Strategies for Economic Growth: Micro, Small and Medium Enterprises in Rural Areas of Nigeria. Business and Economics Journal, 2016, 7: 4

Riti, J. S., Dankumo, A. M. and Gubak, H. D. (2015). Entrepreneurship and Environmental Sustainability: Evidence From Nigeria. Journal of Economics and Sustainable Development, Volume 6, No. 8, 2015

Schmithusen, F., Kaiser, B., Schmidhauser, A., Mellinghof, S., Perchthaler, K. and Kammerhofer, A. W. (2014). Entrepreneurship and Management in Forestry and Wood Processing - Principles of Business Economics and Management Processes. First published 2014 by Routledge, Taylor and Francis Group, London and New York, Routledge Explorations in Environmental Economics No 42; 496 pp. 